\title{
microRNA-1/133a and microRNA-206/133b clusters: Dysregulation and functional roles in human cancers
}

\author{
Nijiro Nohata ${ }^{1,2}$, Toyoyuki Hanazawa ${ }^{2}$, Hideki Enokida ${ }^{3}$, Naohiko Seki ${ }^{1}$ \\ ${ }^{1}$ Department of Functional Genomics, Chiba University Graduate School of Medicine, Chiba, Japan \\ ${ }^{2}$ Department of Otorhinolaryngology/Head and Neck Surgery, Chiba University Graduate School of Medicine, Chiba, Japan \\ ${ }^{3}$ Department of Urology, Graduate School of Medical and Dental Sciences, Kagoshima University, Kagoshima, Japan \\ Correspondence to: Naohiko Seki, email: naoseki@faculty.chiba-u.jp
}

Keywords: cancer, miRNA, miR-1, miR-133a, miR-133b, miR-206

Received: January 25, 2012, Accepted: January 25, 2012,

Published: February 4, 2012

Copyright: @ Nohata et al. This is an open-access article distributed under the terms of the Creative Commons Attribution License, which permits unrestricted use, distribution, and reproduction in any medium, provided the original author and source are credited.

\section{ABSTRACT:}

MicroRNAs (miRNAs) are endogenous short non-coding RNA molecules that regulate gene expression by repressing translation or cleaving RNA transcripts in a sequence-specific manner. A growing body of evidence suggests that miRNAs are aberrantly expressed in many human cancers and that they play significant roles in the initiation, development and metastasis of human cancers. Genomewide miRNA expression signatures provide information on the aberrant expression of miRNAs in cancers rapidly and precisely. Recently, studies from our group and others revealed that microRNA-1 (miR-1), microRNA-133a (miR-133a), microRNA133b (miR-133b) and microRNA-206 (miR-206) are frequently downregulated in various types of cancers. Interestingly, miR-1-1/miR-133a-2, miR-1-2/miR-133a-1, and $\mathrm{miR}-206 / \mathrm{miR}-133 \mathrm{~b}$ form homologous clusters in three different chromosomal regions of the human genome $-20 q 13.33,18 q 11.2$ and $6 p 12.2$, respectively. Here we review recent findings on the aberrant expression and functional significance of the miR-1/miR-133a and miR-206/miR-133b clusters in human cancers.

\section{INTRODUCTION}

microRNAs (miRNAs) are a class of small noncoding RNA molecules consisting of 19-22 nucleotides that play important roles in a variety of biological processes, including development, differentiation, apoptosis, cell proliferation and cellular senescence [1-3]

miRNAs are evolutionarily conserved and located either within the introns or exons of protein-coding genes $(70 \%)$ or in intergenic regions (30\%) [4]. Most intronic and exonic miRNAs are derived from their host gene, suggesting that they are transcribed concurrently with their host transcript. The others are transcribed from intergenic regions or gene deserts as separate transcriptional units [4] (Figure 1). So far, 1527 human miRNAs have been registered at miRBase in release 18.0 ( http://microrna. sanger.ac.uk/). Despite the small size of these molecules through several intracellular processing [5], mature miRNAs broadly regulate gene expression through translational repression and mRNA cleavage, mainly due to the lack of a requirement for perfect sequence complementarity for target binding [6,7] (Figure 1). Bioinformatic predictions indicate that miRNAs regulate more than $30 \%$ of protein-coding genes [8].

The importance of miRNA in cancer was first recognized when miRNA genes were found to be specifically deleted in leukemia [9]. Subsequent reports have shown that miRNAs are differentially expressed in many cancers [10]. Although the biological functions of miRNAs remain mostly unknown, many recent studies suggest that miRNAs contribute to the initiation and development of various types of cancer [11,12]. Recent reports show that some miRNAs actually control the condition of major cancer-related signaling molecules [13], such as p53 family [13,14], retinoblastoma (Rb) [15] and epidermal growth factor receptor (EGFR) [16]. MiRNAs can be separated into two main classes: those which are oncogenic and those which are tumor suppressive. Overexpressed miRNAs can act as oncogenes by repressing tumor suppressor genes, whereas underexpressed miRNAs can function as tumor suppressors by negatively regulating oncogenes [17-19]. 
The miR-15a and miR-16 clusters, for example, are well known to act as tumor suppressors by targeting multiple oncogenes, including BCL2, MCL1, CCND1 and WNT3A [20], whereas the miR-17-92 cluster (also known as oncomiR-1) is recognized as oncogenic [21]. Many cluster miRNAs have been highly conserved over the course of evolution [22]. These facts indicate that miRNA clusters involve not only in normal biological process but also in development of cancers .

\section{Genes of the miR-1/miR-133a and miR-206/miR- $133 \mathrm{~b}$ clusters}

Many miRNAs are expressed in a tissue-specific manner, indicating that they play important roles in many aspects of development and physiology $[1,23]$. Among these are miR-1/133a and miR-206/133b, which are highly conserved in the musculatures of flies, mice and humans and are well characterized as muscle-specific miRNAs so-called myomiRs [24,25]. miR-1-1/miR-133a-2, miR1-2/miR-133a-1, and miR-206/miR-133b form clusters in three different chromosomal regions in the human genome $-20 q 13.33,18 q 11.2$, and $6 \mathrm{p} 12.2$, respectively. miR-1-1/ miR-133a-2 is in an intron of the C20orf166 gene, miR-1$2 / \mathrm{miR}-133 \mathrm{a}-1$ is in an intron of the MIB1 gene, and miR$206 / 133$ b is in an intergenic region (Figure 2). miR-206 is similar to miR-1 in terms of expression and function, but its sequence differs from the miR-1 sequence by four nucleotides [26] (Figure 3). miR-133a-1 and miR-133a-2 possess identical mature sequences. miR-133b differs from miR-133a by a single nucleotide at the 3' end [26] (Figure 4).

It has been reported that the expression of miRNAs located within $50 \mathrm{~Kb}$ of one another is highly correlated across 24 different human organs, suggesting that $50 \mathrm{~Kb}$ might be a useful functional definition of miRNA clusters [27]. It is not rare for miRNA clusters to have paralogues or homologues in other human chromosome regions [28]. It is well known that the miR-17-92 cluster (chromosome 13q31.3) has two paralogous clusters miR-106a-363 (chromosome Xq26.2) and miR-106b-25 (chromosome 7q22.1). miR-17-92 cluster function as oncogenes in numerous cancers [21]. On the other hand, miR-106b-25 acts as an important regulator of neural stem cell proliferation and neuronal differentiation [29]. The miR-23a 27a 24-2 cluster (chromosome 19p13.13) has one homologue - miR-23b 27b 24-1 (chromosome $9 q 22.32$ ), which are related to various human health and disease status [30].

\section{Aberrant expression of miR-1, miR-133a, miR- $133 \mathrm{~b}$ and $\mathrm{miR}-206$ in cancers}

Using high-throughput technology, such as miRNA oligonucleotide arrays and quantitative RT-PCR for validation, many studies have found associations between

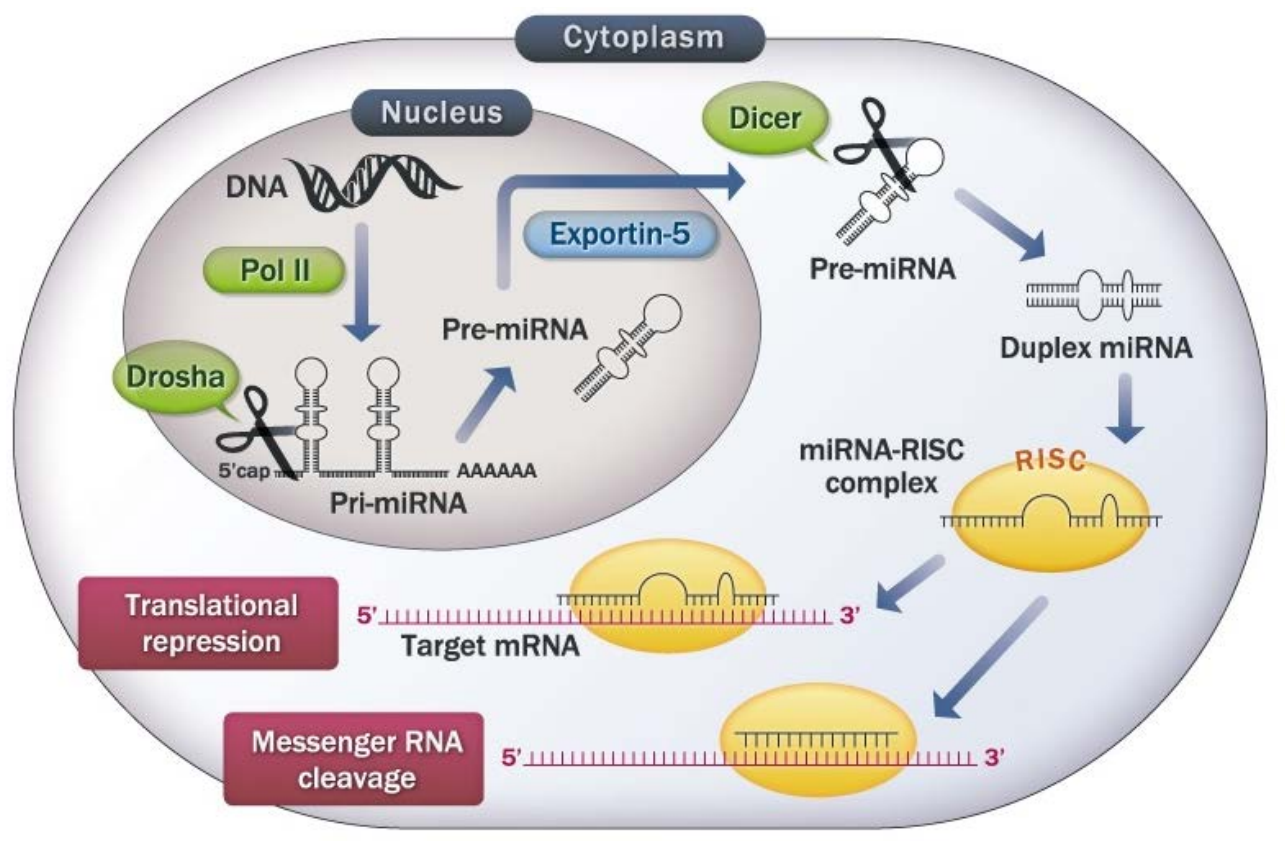

Figure 1: The microRNA biosynthetic pathway. miRNA genes are transcribed by RNA polymerase II (Pol II). The resulting long transcript is capped with a specially-modified nucleotide at the 5' end, polyadenylated with multiple adenosines and spliced. The product is called primary miRNA (Pri-miRNA). Drosha crops Pri-miRNA into precursor-miRNA (Pre-miRNA). Pre-miRNA hairpins are exported from the nucleus to the cytoplasm by Exportin-5. In the cytoplasm, the pre-miRNA hairpin is cleaved by the RNase III enzyme Dicer. One strand is taken into the RNA-induced silencing complex (RISC), where the miRNA and its target interact. miRNAs that bind to mRNA targets with perfect matching induce mRNA cleavage, whereas translational repression is induced when matching is imperfect. 
miRNA expression levels and tumor type, grade, response to treatment and prognosis [31-36]. These studies indicate the potential for miRNAs to serve as useful markers of disease state and prognosis and predictors of drug resistance. These high-throughput analyses have found miR-1, miR-133a, miR-133b and miR-206 to be altered in various types of cancers. Except for one report about multiple myeloma [37], studies on miR-1, miR-133a, miR-133b and miR-206 have found them all to be downregulated in many types of cancer (Table 1). We and other researchers have reported that the expression levels of miR-1 and miR-133a are significantly reduced in and correlated with maxillary sinus squamous cell carcinoma (SCC), renal cell carcinoma (RCC) and rhabdomyosarcoma (RMS) [38-40].

It is plausible that these miRNAs are silenced by epigenetic modification. DNA methylation-mediated miR1 silencing was suggested in hepatocellular carcinoma
(HCC) after treatment with 5-aza-cytidine [41], and methylation of an miR-1-1 promoter $\mathrm{CpG}$ island has been found frequently in primary colorectal cancer (CRC) and colorectal adenoma [42]. In lung cancer cells, miR1 suppression might be caused by hypoacetylation of nucleosomal histones and not DNA methylation [43].

With regard to expression levels in tumor tissues, high expression levels of miR-133b were found to be associated with poor prognosis for progression free survival in 106 patients with bladder cancer (BC) [44]. In contrast, low expression levels of miR-133b in tumor tissues were found to be associated with poor prognosis for overall survival $(n=43)$ and positive lymph node metastasis $(n=45)$ in CRC [45]. In RMS, low expression levels of miR-206 in tumor tissues were shown to be correlated with poor prognosis for overall survival $(n=159)$, but no difference was found in the expression levels of miR-1 [46].

(A) Chromosome 20q13.33

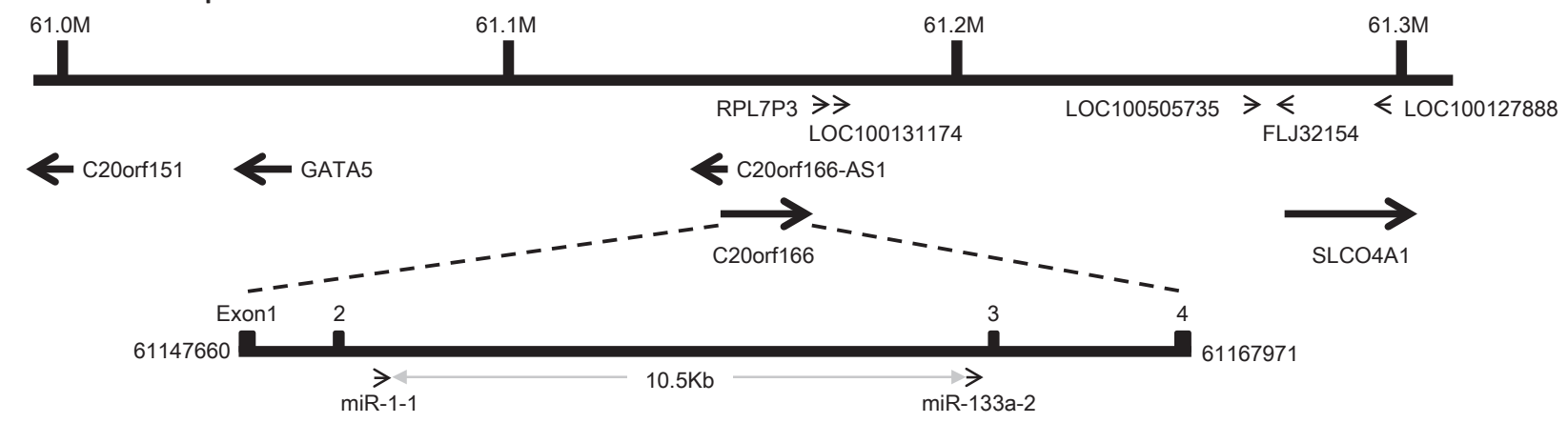

(B) Chromosome 18q11.2

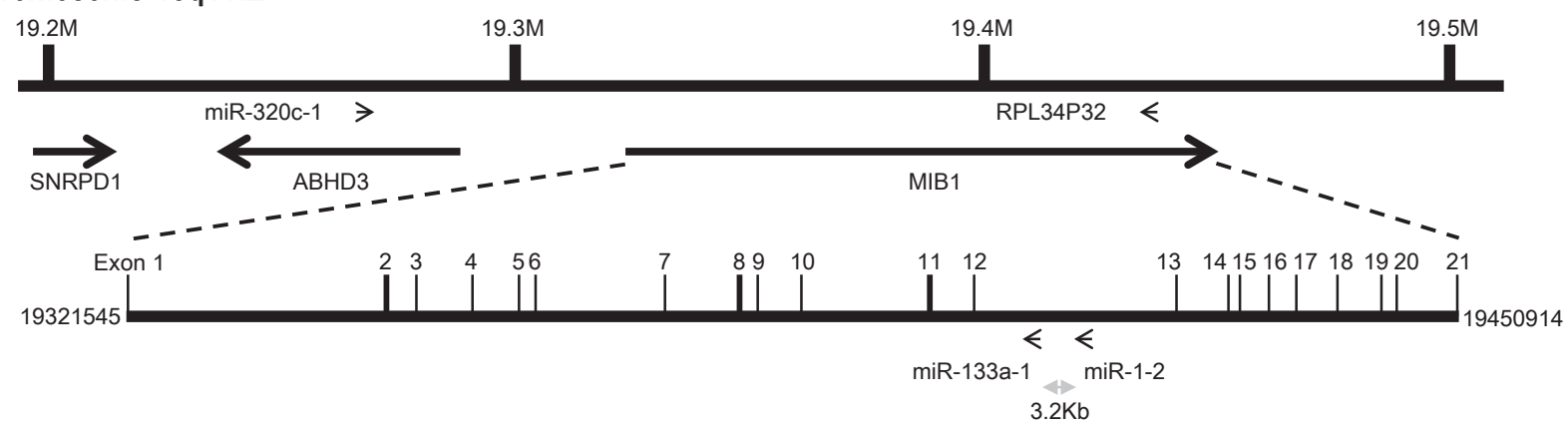

(C) Chromosome 6p12.2

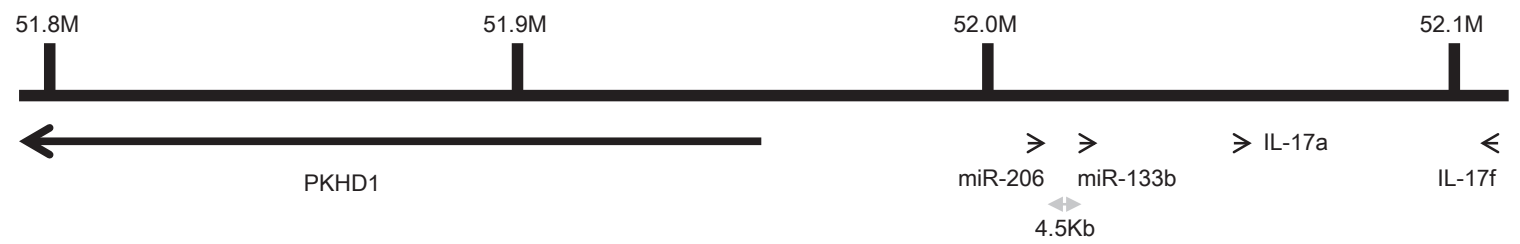

Figure 2: Gene structure of the human miR-1/133a and miR-206/133b clusters.(A) miR-1-1 and miR-133a-2 are in an intron of the C20orf166 gene on human chromosome 20q13.33, where they are separated by $10.5 \mathrm{~kb}$. (B) miR-1-2 and miR-133a-1 are in a complementary strand of an intron of the MIB1 gene on human chromosome 18q11.2, where they are separated by $3.2 \mathrm{~kb}$.(C) miR-206 and miR-133b are clustered together on human chromosome $6 \mathrm{p} 12.2$, where they are separated by $4.5 \mathrm{~kb}$. 
Circulating miR-1, miR-133a, miR-133b and miR206 as potential diagnostic markers

As noninvasive diagnostic tools, serum miRNAs have the potential to be fingerprints for diseases because human serum and plasma contain a number of stable miRNAs, and the differential expression patterns of serum miRNAs are intrinsic to a specific disease $[47,48]$. miR-1 may serve as a predictor for overall survival in non-small cell lung cancer (NSCLC). Low serum expression levels of miR-1 were found to be associated with poor prognosis in NSCLC [49]. Similarly, miR-206 expression levels in serum might be used to distinguish RMS from non-RMS tumors (sensitivity of 1.0 and specificity of 0.913) [50]. In a study of gastric cancer (GC), a combination of five serum miRNAs (miR-1, miR-20a, miR-27a, miR-34 and miR-423) was a better indicator for cancer detection than conventional markers, such as CEA and CA19-9 (sensitivity of 0.8 and specificity of 0.81 ) [51]. Expression of these five serum miRNAs was significantly higher in GC patients. Moreover, risk score values based on the expression of the five serum miRNAs was positively correlated with clinical stage [51].

\section{Functional significance of miR-1, miR-133a, miR-} $133 \mathrm{~b}$ and miR-206 in cancers

As miR-1, miR-133a, miR-133b and miR-206 are mostly downregulated in cancers, gain-of-function experiments are a feasible way to evaluate the functional significance of these miRNAs in various cancers.

Ectopic expression of miR-1 reportedly inhibits cell growth in HCC [41], RMS [40,52], lung cancer [43], maxillary sinus SCC [38], head and neck squamous cell carcinoma (HNSCC) [53], laryngeal SCC [54], thyroid cancer [55-57], prostate cancer (PCa) [58], BC [59], RCC [39] and CRC [42]. miR-1 overexpression has also been reported to induce apoptosis through enhanced activation of caspases 3 and 7 and cleavage of their substrate, PARP1 , in lung cancer cells [43]. Our group also revealed that miR-1 overexpression induces apoptosis in maxillary sinus SCC [38], HNSCC [53], BC [59] and RCC cells [39] by fluorescence-activated cell sorting (FACS) analysis. FACS, TdT-mediated dUTP nick end labeling (TUNEL) and caspase assays revealed that miR-1 induces apoptosis in nasopharyngeal carcinoma cells [60]. As for cell cycle distribution, miR-1 was found to induce $\mathrm{G} 0 / \mathrm{G} 1$ arrest

Table 1: Altered expression of miR-1, miR-133a, miR-133b and miR-206 in cancers

\begin{tabular}{|l|l|l|l|l|l|}
\hline Type of Cancer & 1 & 133a & 133b & 206 & Reference \\
\hline HNSCC & D & D & D & - & {$[53,74,78,83]$} \\
\hline Maxillary sinus SCC & D & D & - & - & {$[38]$} \\
\hline Tongue SCC & - & D & D & - & {$[68]$} \\
\hline Hypopharyngeal SCC & D & - & - & - & {$[84]$} \\
\hline Esophageal SCC & D & D & D & - & {$[69]$} \\
\hline Thyroid cancer & D & - & - & - & {$[56,57]$} \\
\hline Lung SCC & - & D & - & D & {$[67]$} \\
\hline Lung cancer & D & - & D & D & {$[43,79]$} \\
\hline Gastric cancer & - & - & D & - & {$[85]$} \\
\hline PDAC & - & D & - & - & {$[86]$} \\
\hline HCC & D & - & - & - & {$[41]$} \\
\hline RCC & D & D & - & - & {$[39]$} \\
\hline Bladder cancer & D & D & D & - & {$[59,87]$} \\
\hline Prostate cancer & D & D & - & - & {$[58,88]$} \\
\hline Colorectal cancer & D & D & D & - & {$[42,70,89-91]$} \\
\hline Rhabdomyosarcoma & D & D & - & D & {$[40,46,52,62]$} \\
\hline ERa positive breast cancer & - & - & - & D* & {$[64]$} \\
\hline ERa positive EEC & - & - & - & D* & {$[65]$} \\
\hline Multiple Myeloma & U & U & - & - & {$[37]$} \\
\hline *: Compared with ERa negative cancer \\
$\begin{array}{l}\text { D: Downregulated, U: Upregulated, SCC: squamous cell carcinoma } \\
\text { HNSCC: head and neck squamous cell carcinoma, PDAC: pancreatic ductal } \\
\text { adenocarcinoma, HCC: hepatocellar carcinoma, RCC: Renal cell carcinoma }\end{array}$ \\
\hline ERa: estrogen receptor alpha, EEC: endometorial endometorioid carcinoma \\
\hline
\end{tabular}


in lung cancer [43], HNSCC [53], RCC [39] and RMS cells [40,52] and G2 arrest in HCC cells [41]. Evaluations of cell migration and invasion activities have also been conducted by wound healing assay, Boyden chamber assay and invasion chamber assay. miR-1 has been found to inhibit cancer cell migration and invasion in lung cancer [43], thyroid cancer [56], HNSCC [53], laryngeal SCC [54], BC [59], RCC [39], PCa [58], RMS [52] and CRC cells [42]. In vivo, a tumor suppressive function for miR-1 was shown in lung cancer and RMS in xenotransplanted mice $[43,52]$.

In acute myeloid leukemia (AML) cell lines, overexpression of miR-1 promotes cell proliferation, suggesting that miR-1 might act as an oncogene in hematologic malignancy [61]. It is interesting to note that the commonalities and differences in miR-1 function
hsa-miR-1-1

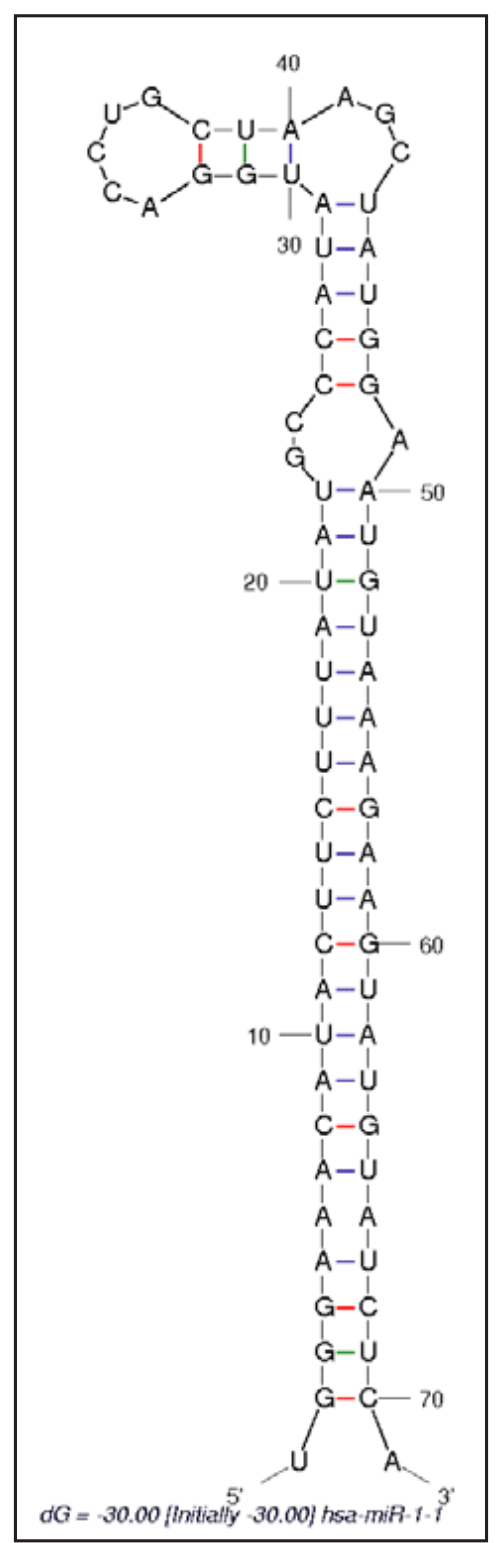

hsa-miR-1-2

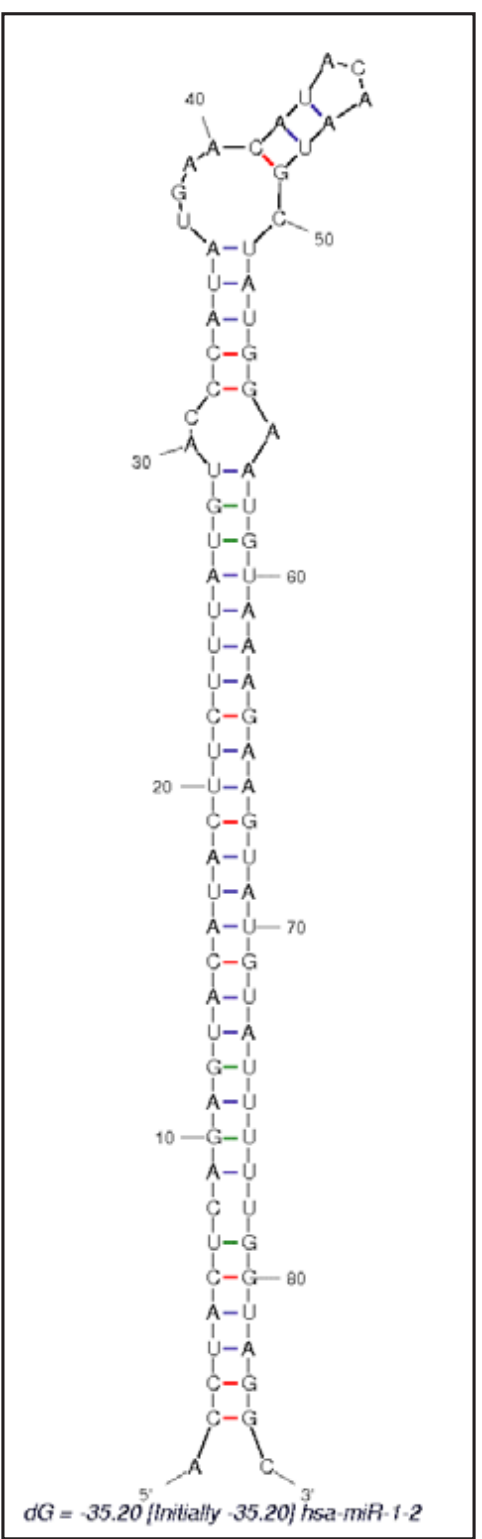

hsa-miR-206

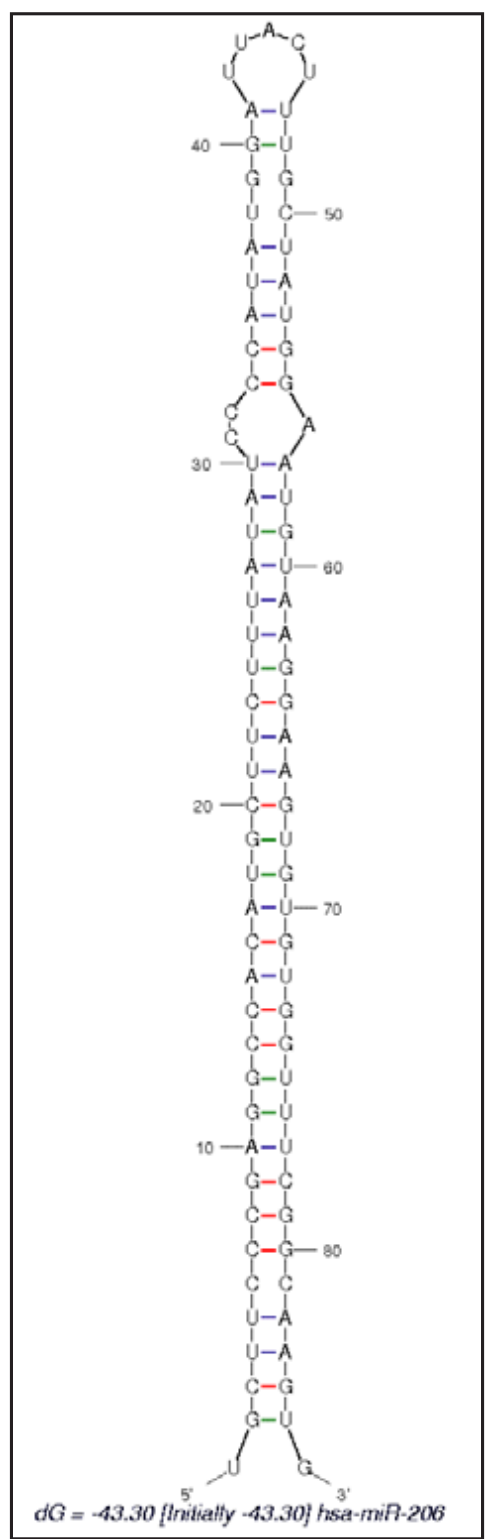

\section{miR-1 : UGGAAUGUAAAGAAGUAUGUAU miR-206: UGGAAUGUAAGGAAGUGUGUGG}

Figure 3: Alignment of miR-1-1, miR-1-2 and miR-206. The structures of precursor miR-1-1, miR-1-2 and miR-206 as constructed by the Mfold program [92] (http://mfold.rna.albany.edu/). The respective Pre-miRNA sequences were entered into the program. Each mature miRNA sequence is shown below with red characters indicating variant nucleotides. 
depend on the type of malignant cells.

With regard to miR-206, a homologue of miR-1, the articles of its functional role are reported in RMS, breast cancer, endometrial endometorioid carcinoma (EEC) and lung cancer. Ectopic miR-206 expression inhibits cell growth in RMS $[46,52,62]$, breast cancer [63,64], EEC [65] and lung cancer cells [66]. Moreover, FACS analysis revealed that miR-206 induced apoptosis in RMS [46,52,62], EEC [65] and lung cancer cells [66], and induced G0/G1 arrest in RMS [46,52,62], breast [63] and lung cancer cells [66]. Cell migration and invasion activities are also inhibited by miR-206 in RMS $[46,52,62]$, EEC [65] and lung cancer cells [66]. In RMS cells, miR-206 increased the number of myosin heavy chain (MHC)-positive cells, which means that miR-206 induced myogenic differentiation in RMS cells. Consistent with these results, miR-206 suppressed the expression of cyclin D1 and phospho-retinoblastoma protein and upregulated p21 and myogenin [62]. In vivo, a tumor suppressive function for miR-206 has been shown in RMS in xenotransplanted mice [62].

Ectopic miR-133a has been shown to inhibit cancer cell growth in lung SCC [67], maxillary sinus SCC [38], tongue SCC [68], esophageal squamous cell carcinoma (ESCC) [69], PCa [58], BC [59], RCC [39] and RMS [40], and miR-133a was found to induce apoptosis in maxillary sinus SCC [38], tongue SCC [68], BC [59], and RCC cells [39], whereas miR-133a induced G2 arrest in RCC cells [39]. Cell migration and invasion activities are also inhibited by miR-133a in ESCC [69], PCa [58], BC

hsa-miR-133a-1 hsa-miR-133a-2

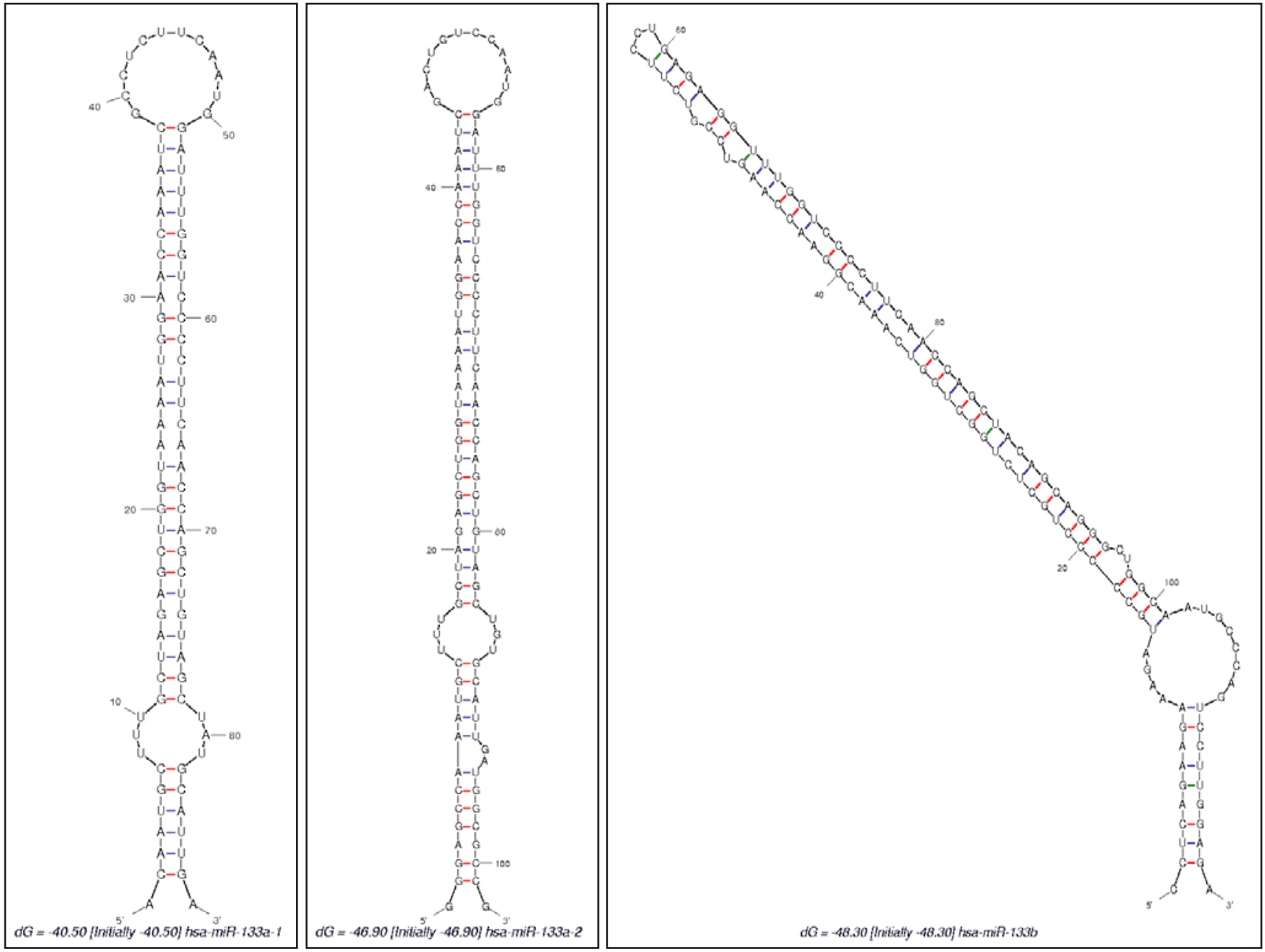

\section{miR-133a: UUUGGUCCCCUUCAACCAGCUG \\ miR-133b: UUUGGUCCCCUUCAACCAGCUA}

Figure 4: Alignment of miR-133a-1, miR-133a-2 and miR-133b. The structures of precursor miR-133a-1, miR-133a-2 and miR$133 \mathrm{~b}$ as constructed by the Mfold program [92] (http://mfold.rna.albany.edu/). The respective Pre-miRNA sequences were entered into the program. Each mature miRNA sequence is shown below with red characters indicating variant nucleotides. 
[59] and RCC [39]. miR-133b, a homologue of miR-133a, also inhibited tumor growth in tongue SCC [68], ESCC [69], and CRC cells [70]. Overexpression of miR-133b has been shown to induce apoptosis and G1 cell cycle arrest in CRC cells [70], whereas cell invasion activity was inhibited by miR-133b in ESCC cells [69]. In vivo, a tumor suppressive function for miR-133b was shown in $\mathrm{CRC}$ in xenotransplanted mice [70].

\section{miR-1-, miR-133a-, miR-133b- and miR-206- regulated molecular networks in cancers}

Each miRNA theoretically has the potential to regulate a number of specific mRNAs, as the recognition of miRNA targets depends on the sequence complementarity of seed regions, which have lengths of about 7 nucleotides [1]. Several optimized experimental approaches can lead to identify actual miRNA target genes in a presented cell phenotype [71]. Conducting qPCR, western blotting, and reporter assays and using bioinformatic prediction programs, recent research has identified several targets of miR-1, miR-133a, miR-133b and miR-206 (Table 2). These targets potentially contribute to specific functional readouts of miR-1, miR-133a, miR-133b and miR-206. For example, the tumor suppressive function of miR-1 is partially accounted for by its repression of the oncogenic target met proto-oncogene (MET) in lung cancer [43], HCC [41], papillary thyroid cancer [57] and RMS [52]. To our knowledge, other validated oncogenic targets of miR-1 are forkhead box P1 (FOXP1) and histone deacetylase 4 (HDAC4) in lung cancer [43] and HCC [41]; LIM and SH3 protein 1 (LASP1) in BC [72]; pim-1 oncogene (PIM1) in lung cancer [43]; cyclin D2 (CCND2), chemokine (C-X-C motif) receptor 4 (CXCR4) and chemokine (C-X-C motif) ligand 12 (CXCL12) in thyroid cancer [56]; purine nucleoside phosphorylase (PNP) in maxillary sinus SCC [38] and PCa [58]; transgelin 2 (TAGLN2) in maxillary
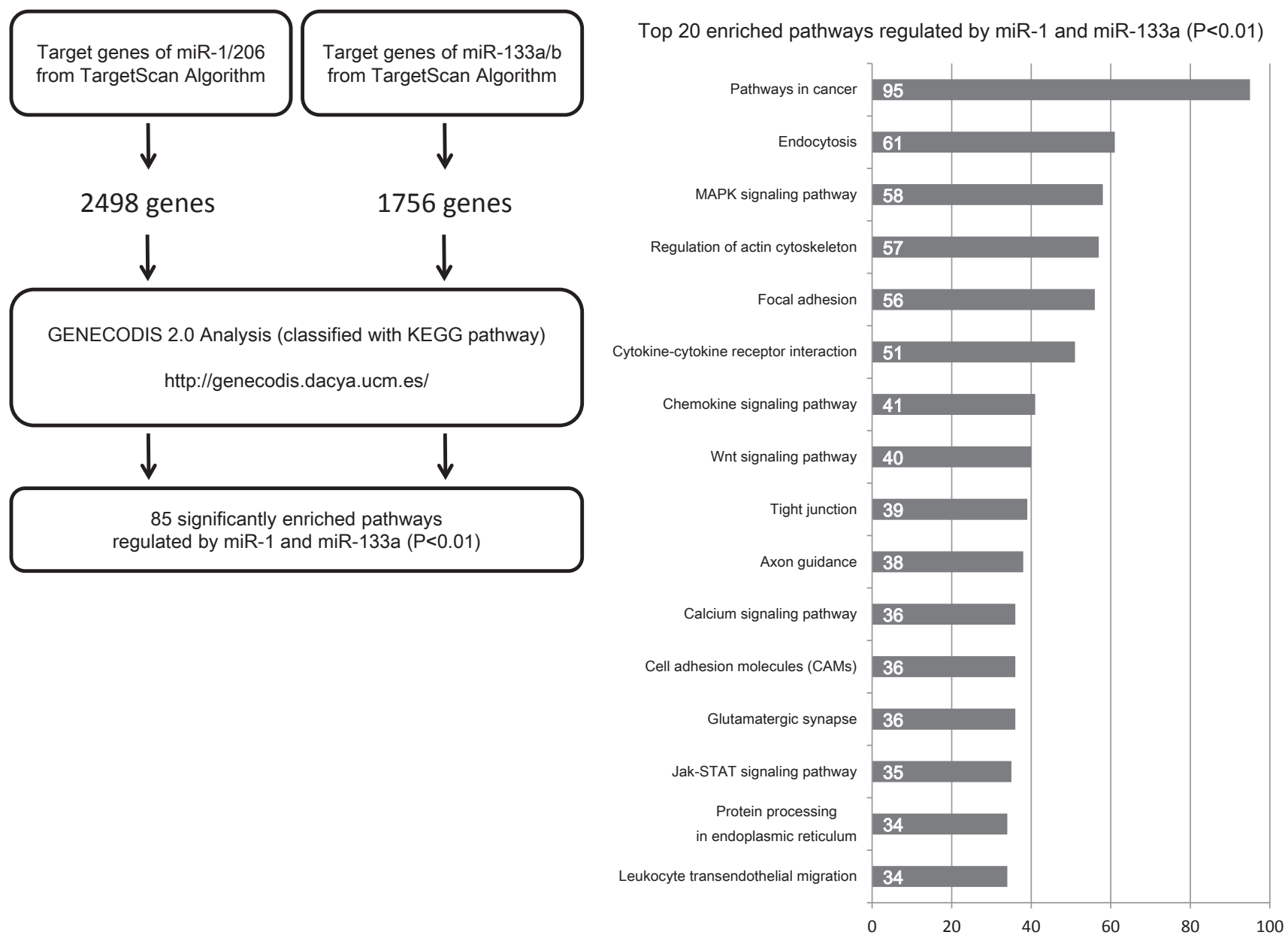

Figure 5: Workflow for the bioinformatic analysis of target genes of miR-1, miR-133a, miR-133b and miR-206. A total of 3716 genes were identified by the TargetScan program as predicted targets of miR-1, miR-133a, miR-133b and miR-206. The predicted target genes of miR-1 are the same as those of miR-206, and those of miR-133a are the same as those of miR-133b, due to the identical sequences of their seed regions. The genes were then analyzed and characterized in KEGG (Kyoto Encyclopedia of Genes and Genomes) pathway categories [93] by the GENECODIS program (Left). Twenty significantly enriched signaling pathways are shown in descending order of the number of genes contained in each pathway (Right). 
sinus SCC [38]; HNSCC [53], BC [59] RCC [39], and prothymosin alpha (PTMA) in nasopharyngeal carcinoma [60]; fibronectin 1 (FN1) in laryngeal SCC [54]; and splicing factor arginine/serine-rich 9 (SRSF9) in BC [73]. Validated targets of miR-133a are actin-related protein $2 / 3$ complex, subunit 5 (ARPC5) in lung SCC [67]; caveolin 1 (CAV1) in HNSCC [74]; fascin homolog 1 (FSCN1) in BC [75] and ESCC [69]; glutathione S-transferase pi 1 (GSTP1) in HNSCC [76] and BC [77]; LASP1 in BC [72]; pyruvate kinase, muscle (PKM2) in tongue SCC [78]; PNP in maxillary sinus SCC [38] and PCa [58]; and TAGLN2 in maxillary sinus SCC [38] and BC [59]. miR-133b targets MET in CRC cells [70]; PKM2 in tongue SCC
[68]; FSCN1 in ESCC [69] and myeloid cell leukemia sequence 1 (MCL1); and BCL2-like 2 (BCL2L2) in lung cancer [79]. MCL1 is also indirectly suppressed by miR-1 in lung cancer [43]. Target genes of miR-206 are MET in RMS [52,62]; estrogen receptor 1 (ESR1, alias; ER $\alpha$ ) in breast cancer [63] and EEC [65]; and notch 3 (NOTCH3) in HeLa cells [80]. As mentioned above, although the sequence of each seed region is different, some targets, such as MET, TAGLN2, PNP and LASP1, are commonly regulated by the $\mathrm{miR}-1 / \mathrm{miR}-133 \mathrm{a}$ and/or $\mathrm{miR}-206 / \mathrm{miR}$ $133 \mathrm{~b}$ clusters. In addition, TargetScan, an miRNA target prediction program (http://www.targetscan.org/), has revealed, interestingly, that the miR-1 targets; FOXP1 and

Table 2: Validated oncogene targets of miR-1, miR-133 and miR-206 in cancers

\begin{tabular}{|c|c|c|c|}
\hline miRNA & Symbol & Gene name & Reference \\
\hline \multirow[t]{14}{*}{1} & CCND2 & cyclin D2 & {$[56]$} \\
\hline & CREB1 & cAMP-responsive element binding protein 1 & [55] \\
\hline & CXCL12 & chemokine (C-X-C motif) ligand 12 & [56] \\
\hline & CXCR4 & chemokine (C-X-C motif) receptor 4 & [56] \\
\hline & FN1 & fibronectin 1 & [54] \\
\hline & FOXP1 & forkhead box P1 & {$[41,43]$} \\
\hline & HDAC4 & histone deacetylase 4 & {$[41,43]$} \\
\hline & LASP1 & LIM and SH3 protein 1 & [72] \\
\hline & MET & met proto-oncogene & {$[41,43,52,57]$} \\
\hline & PIM1 & pim-1 oncogene & [43] \\
\hline & PNP & purine nucleoside phosphorylase & {$[38,58]$} \\
\hline & PTMA & prothymosin alpha & [60] \\
\hline & SRSF9 & splicing factor arginine/serine-rich 9 & [73] \\
\hline & TAGLN2 & transgelin 2 & {$[38,39,53,59]$} \\
\hline \multirow[t]{8}{*}{ 133a } & ARPC5 & actin-related protein $2 / 3$ complex, subunit 5 & [67] \\
\hline & CAV1 & caveolin 1 , caveolae protein, $22 \mathrm{kDa}$ & [74] \\
\hline & FSCN1 & fascin homolog 1, actin-bundling protein & {$[69,75]$} \\
\hline & GSTP1 & glutathione S-transferase pi 1 & {$[76,77]$} \\
\hline & LASP1 & LIM and SH3 protein 1 & [72] \\
\hline & PKM2 & pyruvate kinase, muscle & [68] \\
\hline & PNP & purine nucleoside phosphorylase & {$[38,58]$} \\
\hline & TAGLN2 & transgelin 2 & {$[38,39,53,59]$} \\
\hline \multirow[t]{5}{*}{$133 b$} & BCL2L2 & BCL2-like 2 & [79] \\
\hline & FSCN1 & fascin homolog 1, actin-bundling protein & [69] \\
\hline & MCL1 & myeloid cell leukemia sequence 1 (BCL2-related) & [79] \\
\hline & MET & met proto-oncogene & [70] \\
\hline & PKM2 & pyruvate kinase, muscle & [68] \\
\hline \multirow[t]{3}{*}{206} & ESR1 & estrogen receptor 1 & {$[63,65]$} \\
\hline & MET & met proto-oncogene & {$[52,62]$} \\
\hline & NOTCH3 & notch 3 & [80] \\
\hline
\end{tabular}


HDAC4 have putative target sites for miR-133a or miR133b, whereas miR-133b target; BCL2L2 also has putative miR-1 or miR-206 target sites. These facts suggest that miR-1/miR-133a and miR-206/miR-133b clusters might coordinately affect downstream pathways.

\section{Computational analysis of miR-1-, miR-133a-, miR-133b- and miR-206-regulated molecular networks}

To reveal the biological significance of these clusters, a list of predicted targets of miR-1 or miR-206 and miR$133 \mathrm{a}$ or miR-133b was constructed using TargetScan (Additional Table 1). Putative miR-1 or miR-206 targets exist in 2498 genes, and putative miR-133a or miR-133b targets are found in 1756 genes. The total number of genes targeted by miR-1 or miR-206 and miR-133a or miR-133b is 3716. Common targets of miR-1 or miR-206 and miR$133 \mathrm{a}$ or miR-133b are 538 genes, which is $21.5 \%$ of miR1 or miR-206 targets and $30.6 \%$ of miR-133a or miR-133b targets (Additional Table 1).

To identify the biological processes or pathways potentially regulated by the $\mathrm{miR}-1 / \mathrm{miR}-133 \mathrm{a}$ and $\mathrm{miR}$ 206/miR-133b clusters, we performed GENECODIS analysis [81,82] with our predicted target list. The GENECODIS analysis revealed many signaling pathways (Figure 5). Several cancers, including $\mathrm{PCa}$, pancreatic cancer, lung cancer, AML, RCC, CRC, BC and thyroid cancer, are among the statistically enriched categories (Additional Table 2), and it is worth mentioning that miR1, miR-133a, miR-133b and miR-206 are differentially expressed in these types of human malignancies. This bioinformatic analysis indicates that the miR-1/miR133a and miR-206/miR-133b clusters might supplement each other to regulate several cancer pathways, such as cell growth, cell apoptosis, cell cycle, invasion and angiogenesis (Additional Figure 1). Thus, cooperative gene regulation by miRNAs is an interesting subject, and it may change our understanding of miRNA-mRNA interactions.

\section{CONCLUSION}

miRNAs are important modulators of gene expression, and they contribute to a variety of biological processes, including proliferation, differentiation and apoptosis. The first evidence for their involvement in cancer was the finding in 2002 that some miRNAs are specifically deleted in leukemia . Thereafter, an enormous number of articles have been published about miRNAs and cancer. Today, nobody doubts that aberrant expression of miRNAs causes initiation, development and metastasis of human cancers.
Recently, studies from our group and others have shown that downregulation of the miR-1/miR-133a and miR-206/ miR-133b clusters are frequent events in various types of cancer. During evolution of the human genome, clustered miRNAs have developed important roles in maintaining the functions of the human body. Herein, we have reviewed the individual functions of these miRNAs and their regulated molecular targets in cooperation or independently . Elucidation of the intracellular molecular networks regulated by miRNAs is the current difficult challenge. Understanding of the molecular networks controlled by miRNA clusters may be exploited for future cancer treatment.

\section{REFERENCES}

1. Bartel DP. MicroRNAs: genomics, biogenesis, mechanism, and function. Cell. 2004; 116: 281-97.

2. Kloosterman WP, Plasterk RH. The diverse functions of microRNAs in animal development and disease. Dev Cell. 2006; 11: 441-50.

3. Tacutu R, Budovsky A, Yanai H, Fraifeld VE. Molecular links between cellular senescence, longevity and age-related diseases - a systems biology perspective. Aging (Albany NY). 2011; 3: 1178-91.

4. Rodriguez A, Griffiths-Jones S, Ashurst JL, Bradley A. Identification of mammalian microRNA host genes and transcription units. Genome Res. 2004; 14: 1902-10.

5. Melo SA, Esteller M. A precursor microRNA in a cancer cell nucleus: get me out of here! Cell Cycle. 2011; 10: 9225 .

6. Wightman B, Ha I, Ruvkun G. Posttranscriptional regulation of the heterochronic gene lin-14 by lin-4 mediates temporal pattern formation in C. elegans. Cell. 1993; 75: 855-62.

7. Lee RC, Feinbaum RL, Ambros V. The C. elegans heterochronic gene lin-4 encodes small RNAs with antisense complementarity to lin-14. Cell. 1993; 75: 843-54.

8. Filipowicz W, Bhattacharyya SN, Sonenberg N. Mechanisms of post-transcriptional regulation by microRNAs: are the answers in sight? Nat Rev Genet. 2008; 9: 102-14.

9. Calin GA, Dumitru CD, Shimizu M, Bichi R, Zupo S, Noch E, Aldler H, Rattan S, Keating M, Rai K, Rassenti L, Kipps T, Negrini M, Bullrich F, Croce CM. Frequent deletions and down-regulation of micro- RNA genes miR15 and miR16 at 13 q14 in chronic lymphocytic leukemia. Proc Natl Acad Sci U S A. 2002; 99: 15524-9.

10. Calin GA, Sevignani C, Dumitru CD, Hyslop T, Noch E, Yendamuri S, Shimizu M, Rattan S, Bullrich F, Negrini M, Croce CM. Human microRNA genes are frequently located at fragile sites and genomic regions involved in cancers. Proc Natl Acad Sci U S A. 2004; 101: 2999-3004. 
11. Garzon R, Calin GA, Croce CM. MicroRNAs in Cancer. Annu Rev Med. 2009; 60: 167-79.

12. Nelson KM, Weiss GJ. MicroRNAs and cancer: past, present, and potential future. Mol Cancer Ther. 2008; 7: 3655-60.

13. Inui M, Martello G, Piccolo S. MicroRNA control of signal transduction. Nat Rev Mol Cell Biol. 2010; 11: 252-63.

14. Ory B, Ellisen LW. A microRNA-dependent circuit controlling p63/p73 homeostasis: p53 family cross-talk meets therapeutic opportunity. Oncotarget. 2011; 2: 259-64.

15. Noonan EJ, Place RF, Basak S, Pookot D, Li LC. miR-449a causes $\mathrm{Rb}$-dependent cell cycle arrest and senescence in prostate cancer cells. Oncotarget. 2010; 1: 349-58.

16. Erkan EP, Breakefield XO, Saydam O. miRNA signature of schwannomas: possible role(s) of "tumor suppressor" miRNAs in benign tumors. Oncotarget. 2011; 2: 265-70.

17. Davis BN, Hata A. microRNA in Cancer---The involvement of aberrant microRNA biogenesis regulatory pathways. Genes Cancer. 2010; 1: 1100-14.

18. Esquela-Kerscher A, Slack FJ. Oncomirs - microRNAs with a role in cancer. Nat Rev Cancer. 2006; 6: 259-69.

19. Mavrakis KJ, Leslie CS, Wendel HG. Cooperative control of tumor suppressor genes by a network of oncogenic microRNAs. Cell Cycle. 2011; 10: 2845-9.

20. Aqeilan RI, Calin GA, Croce CM. miR-15a and miR-16-1 in cancer: discovery, function and future perspectives. Cell Death Differ. 2010; 17: 215-20.

21. Olive V, Jiang I, He L. mir-17-92, a cluster of miRNAs in the midst of the cancer network. Int J Biochem Cell Biol. 2010; 42: 1348-54.

22. Altuvia Y, Landgraf P, Lithwick G, Elefant N, Pfeffer S, Aravin A, Brownstein MJ, Tuschl T, Margalit H. Clustering and conservation patterns of human microRNAs. Nucleic Acids Res. 2005; 33: 2697-706.

23. Ambros V. The functions of animal microRNAs. Nature. 2004; 431: 350-5.

24. Callis TE, Wang DZ. Taking microRNAs to heart. Trends Mol Med. 2008; 14: 254-60.

25. Townley-Tilson WH, Callis TE, Wang D. MicroRNAs 1, 133, and 206: critical factors of skeletal and cardiac muscle development, function, and disease. Int J Biochem Cell Biol. 2010; 42: 1252-5.

26. Chen JF, Mandel EM, Thomson JM, Wu Q, Callis TE, Hammond SM, Conlon FL, Wang DZ. The role of microRNA-1 and microRNA-133 in skeletal muscle proliferation and differentiation. Nat Genet. 2006; 38: 22833.

27. Baskerville S, Bartel DP. Microarray profiling of microRNAs reveals frequent coexpression with neighboring miRNAs and host genes. RNA. 2005; 11: 241-7.

28. Yu J, Wang F, Yang GH, Wang FL, Ma YN, Du ZW, Zhang JW. Human microRNA clusters: genomic organization and expression profile in leukemia cell lines. Biochem Biophys
Res Commun. 2006; 349: 59-68.

29. Brett JO, Renault VM, Rafalski VA, Webb AE, Brunet A. The microRNA cluster miR-106b 25 regulates adult neural stem/progenitor cell proliferation and neuronal differentiation. Aging (Albany NY). 2011; 3: 108-24.

30. Chhabra R, Dubey R, Saini N. Cooperative and individualistic functions of the microRNAs in the miR23a 27a 24-2 cluster and its implication in human diseases. Mol Cancer. 2010; 9: 232.

31. Chan E, Patel R, Nallur S, Ratner E, Bacchiocchi A, Hoyt K, Szpakowski S, Godshalk S, Ariyan S, Sznol M, Halaban R, Krauthammer M, Tuck D, Slack FJ, Weidhaas JB. MicroRNA signatures differentiate melanoma subtypes. Cell Cycle. 2011; 10: 1845-52.

32. Chan E, Prado DE, Weidhaas JB. Cancer microRNAs: from subtype profiling to predictors of response to therapy. Trends Mol Med. 2011; 17: 235-43.

33. Li X, Zhang Y, Zhang Y, Ding J, Wu K, Fan D. Survival prediction of gastric cancer by a seven-microRNA signature. Gut. 2010; 59: 579-85.

34. Rossi S, Shimizu M, Barbarotto E, Nicoloso MS, Dimitri F, Sampath D, Fabbri M, Lerner S, Barron LL, Rassenti LZ, Jiang L, Xiao L, Hu J, Secchiero P, Zauli G, Volinia S, Negrini M, Wierda W, Kipps TJ, Plunkett W, Coombes KR, Abruzzo LV, Keating MJ, Calin GA. microRNA fingerprinting of CLL patients with chromosome $17 \mathrm{p}$ deletion identify a miR-21 score that stratifies early survival. Blood. 2010; 116: 945-52.

35. Radojicic J, Zaravinos A, Vrekoussis T, Kafousi M, Spandidos DA, Stathopoulos EN. MicroRNA expression analysis in triple-negative (ER, PR and Her2/neu) breast cancer. Cell Cycle. 2011; 10: 507-17.

36. Smits M, Nilsson J, Mir SE, van der Stoop PM, Hulleman E, Niers JM, de Witt Hamer PC, Marquez VE, Cloos J, Krichevsky AM, Noske DP, Tannous BA, Wurdinger T. miR-101 is down-regulated in glioblastoma resulting in EZH2-induced proliferation, migration, and angiogenesis. Oncotarget. 2010; 1: 710-20.

37. Gutierrez NC, Sarasquete ME, Misiewicz-Krzeminska I, Delgado M, De Las Rivas J, Ticona FV, Ferminan E, Martin-Jimenez P, Chillon C, Risueno A, Hernandez JM, Garcia-Sanz R, Gonzalez M, San Miguel JF. Deregulation of microRNA expression in the different genetic subtypes of multiple myeloma and correlation with gene expression profiling. Leukemia. 2010; 24: 629-37.

38. Nohata N, Hanazawa T, Kikkawa N, Sakurai D, Sasaki K, Chiyomaru T, Kawakami K, Yoshino H, Enokida H, Nakagawa M, Okamoto Y, Seki N. Identification of novel molecular targets regulated by tumor suppressive miR-1/ miR-133a in maxillary sinus squamous cell carcinoma. Int J Oncol. 2011; 39: 1099-107.

39. Kawakami K, Enokida H, Chiyomaru T, Tatarano S, Yoshino H, Kagara I, Gotanda T, Tachiwada T, Nishiyama K, Nohata N, Seki N, Nakagawa M. The 
functional significance of miR-1 and miR-133a in renal cell carcinoma. Eur J Cancer. 2011; [Epub ahead of print] PMID: 21745735.

40. Rao PK, Missiaglia E, Shields L, Hyde G, Yuan B, Shepherd CJ, Shipley J, Lodish HF. Distinct roles for miR1 and miR-133a in the proliferation and differentiation of rhabdomyosarcoma cells. FASEB J. 2010; 24: 3427-37.

41. Datta J, Kutay H, Nasser MW, Nuovo GJ, Wang B, Majumder S, Liu CG, Volinia S, Croce CM, Schmittgen TD, Ghoshal K, Jacob ST. Methylation mediated silencing of MicroRNA-1 gene and its role in hepatocellular carcinogenesis. Cancer Res. 2008; 68: 5049-58.

42. Suzuki H, Takatsuka S, Akashi H, Yamamoto E, Nojima M, Maruyama R, Kai M, Yamano HO, Sasaki Y, Tokino T, Shinomura Y, Imai K, Toyota M. Genome-wide profiling of chromatin signatures reveals epigenetic regulation of MicroRNA genes in colorectal cancer. Cancer Res. 2011; 71: 5646-58.

43. Nasser MW, Datta J, Nuovo G, Kutay H, Motiwala T, Majumder S, Wang B, Suster S, Jacob ST, Ghoshal K. Down-regulation of micro-RNA-1 (miR-1) in lung cancer. Suppression of tumorigenic property of lung cancer cells and their sensitization to doxorubicin-induced apoptosis by miR-1. J Biol Chem. 2008; 283: 33394-405.

44. Dyrskjot L, Ostenfeld MS, Bramsen JB, Silahtaroglu AN, Lamy P, Ramanathan R, Fristrup N, Jensen JL, Andersen CL, Zieger K, Kauppinen S, Ulhoi BP, Kjems J, Borre M, Orntoft TF. Genomic profiling of microRNAs in bladder cancer: miR-129 is associated with poor outcome and promotes cell death in vitro. Cancer Res. 2009; 69: 485160.

45. Akcakaya P, Ekelund S, Kolosenko I, Caramuta S, Ozata DM, Xie H, Lindforss U, Olivecrona H, Lui WO. miR185 and miR-133b deregulation is associated with overall survival and metastasis in colorectal cancer. Int $\mathrm{J}$ Oncol. 2011; 39: 311-8.

46. Missiaglia E, Shepherd CJ, Patel S, Thway K, Pierron G, Pritchard-Jones K, Renard M, Sciot R, Rao P, Oberlin O, Delattre O, Shipley J. MicroRNA-206 expression levels correlate with clinical behaviour of rhabdomyosarcomas. Br J Cancer. 2010; 102: 1769-77.

47. Brase JC, Wuttig D, Kuner R, Sultmann H. Serum microRNAs as non-invasive biomarkers for cancer. Mol Cancer. 2010; 9: 306.

48. Kosaka N, Iguchi H, Ochiya T. Circulating microRNA in body fluid: a new potential biomarker for cancer diagnosis and prognosis. Cancer Sci. 2010; 101: 2087-92.

49. Hu Z, Chen X, Zhao Y, Tian T, Jin G, Shu Y, Chen Y, Xu L, Zen K, Zhang C, Shen H. Serum microRNA signatures identified in a genome-wide serum microRNA expression profiling predict survival of non-small-cell lung cancer. J Clin Oncol. 2010; 28: 1721-6.

50. Miyachi M, Tsuchiya K, Yoshida H, Yagyu S, Kikuchi K, Misawa A, Iehara T, Hosoi H. Circulating muscle-specific
microRNA, miR-206, as a potential diagnostic marker for rhabdomyosarcoma. Biochem Biophys Res Commun. 2010; 400: 89-93.

51. Liu R, Zhang C, Hu Z, Li G, Wang C, Yang C, Huang D, Chen X, Zhang H, Zhuang R, Deng T, Liu H, Yin J, Wang $\mathrm{S}$, Zen $\mathrm{K}, \mathrm{Ba} \mathrm{Y}$, Zhang CY. A five-microRNA signature identified from genome-wide serum microRNA expression profiling serves as a fingerprint for gastric cancer diagnosis. Eur J Cancer. 2011; 47: 784-91.

52. Yan D, Dong Xda E, Chen X, Wang L, Lu C, Wang J, Qu J, Tu L. MicroRNA-1/206 targets c-Met and inhibits rhabdomyosarcoma development. J Biol Chem. 2009; 284: 29596-604.

53. Nohata N, Sone Y, Hanazawa T, Fuse M, Kikkawa N, Yoshino H, Chiyomaru T, Kawakami K, Enokida H, Nakagawa M, Shozu M, Okamoto T, Seki N. miR-1 as a tumor suppressive microRNA targeting TAGLN2 in head and neck squamous cell carcinoma. Oncotarget. 2011; 2: $29-44$.

54. Wang F, Song G, Liu M, Li X, Tang H. miRNA-1 targets fibronectin1 and suppresses the migration and invasion of the HEp2 laryngeal squamous carcinoma cell line. FEBS Lett. 2011; 585: 3263-9.

55. Leone V, D'Angelo D, Ferraro A, Pallante P, Rubio I, Santoro M, Croce CM, Fusco A. A TSH-CREB1microRNA loop is required for thyroid cell growth. Mol Endocrinol. 2011; 25: 1819-30.

56. Leone V, D'Angelo D, Rubio I, de Freitas PM, Federico A, Colamaio M, Pallante P, Medeiros-Neto G, Fusco A. MiR1 is a tumor suppressor in thyroid carcinogenesis targeting CCND2, CXCR4, and SDF-1alpha. J Clin Endocrinol Metab. 2011; 96: E1388-98.

57. Yip L, Kelly L, Shuai Y, Armstrong MJ, Nikiforov YE, Carty SE, Nikiforova MN. MicroRNA signature distinguishes the degree of aggressiveness of papillary thyroid carcinoma. Ann Surg Oncol. 2011; 18: 2035-41.

58. Kojima S, Chiyomaru T, Kawakami K, Yoshino H, Enokida H, Nohata N, Fuse M, Ichikawa T, Naya Y, Nakagawa M, Seki N. Tumour suppressors miR-1 and miR-133a target the oncogenic function of purine nucleoside phosphorylase (PNP) in prostate cancer. Br J Cancer. 2011; 2012; 106: 405-13.

59. Yoshino H, Chiyomaru T, Enokida H, Kawakami K, Tatarano S, Nishiyama K, Nohata N, Seki N, Nakagawa M. The tumour-suppressive function of miR-1 and miR-133a targeting TAGLN2 in bladder cancer. Br J Cancer. 2011; 104: 808-18.

60. Wu CD, Kuo YS, Wu HC, Lin CT. MicroRNA-1 induces apoptosis by targeting prothymosin alpha in nasopharyngeal carcinoma cells. J Biomed Sci. 2011; 18: 80.

61. Gomez-Benito M, Conchillo A, Garcia MA, Vazquez I, Maicas M, Vicente C, Cristobal I, Marcotegui N, GarciaOrti L, Bandres E, Calasanz MJ, Alonso MM, Odero MD. EVI1 controls proliferation in acute myeloid leukaemia 
through modulation of miR-1-2. Br J Cancer. 2010; 103: 1292-6.

62. Taulli R, Bersani F, Foglizzo V, Linari A, Vigna E, Ladanyi M, Tuschl T, Ponzetto C. The muscle-specific microRNA miR-206 blocks human rhabdomyosarcoma growth in xenotransplanted mice by promoting myogenic differentiation. J Clin Invest. 2009; 119: 2366-78.

63. Leivonen SK, Makela R, Ostling P, Kohonen P, HaapaPaananen S, Kleivi K, Enerly E, Aakula A, Hellstrom K, Sahlberg N, Kristensen VN, Borresen-Dale AL, Saviranta P, Perala M, Kallioniemi O. Protein lysate microarray analysis to identify microRNAs regulating estrogen receptor signaling in breast cancer cell lines. Oncogene. 2009; 28: 3926-36.

64. Kondo N, Toyama T, Sugiura H, Fujii Y, Yamashita H. miR-206 Expression is down-regulated in estrogen receptor alpha-positive human breast cancer. Cancer Res. 2008; 68: 5004-8.

65. Chen X, Yan Q, Li S, Zhou L, Yang H, Yang Y, Liu $\mathrm{X}$, Wan $\mathrm{X}$. Expression of the tumor suppressor miR206 is associated with cellular proliferative inhibition and impairs invasion in ERalpha-positive endometrioid adenocarcinoma. Cancer Lett. 2012; 314: 41-53.

66. Wang X, Ling C, Bai Y, Zhao J. MicroRNA-206 is associated with invasion and metastasis of lung cancer. Anat Rec (Hoboken). 2011; 294: 88-92.

67. Moriya Y, Nohata N, Kinoshita T, Mutallip M, Okamoto T, Yoshida S, Suzuki M, Yoshino I, Seki N. Tumor suppressive microRNA-133a regulates novel molecular networks in lung squamous cell carcinoma. J Hum Genet. 2012; 57: 38-45.

68. Wong TS, Liu XB, Chung-Wai Ho A, Po-Wing Yuen A, Wai-Man Ng R, Ignace Wei W. Identification of pyruvate kinase type M2 as potential oncoprotein in squamous cell carcinoma of tongue through microRNA profiling. Int $\mathrm{J}$ Cancer. 2008; 123: 251-7.

69. Kano M, Seki N, Kikkawa N, Fujimura L, Hoshino I, Akutsu Y, Chiyomaru T, Enokida H, Nakagawa M, Matsubara H. miR-145, miR-133a and miR-133b: Tumor suppressive miRNAs target FSCN1 in esophageal squamous cell carcinoma. Int J Cancer. 2010; 127: 2804-14.

70. Hu G, Chen D, Li X, Yang K, Wang H, Wu W. miR-133b regulates the MET proto-oncogene and inhibits the growth of colorectal cancer cells in vitro and in vivo. Cancer Biol Ther. 2010; 10: 190-7.

71. Mavrakis KJ, Wendel HG. TargetScreen: an unbiased approach to identify functionally important microRNA targets. Cell Cycle. 2010; 9: 2080-4.

72. Chiyomaru T, Enokida H, Kawakami K, Tatarano S, Uchida Y, Kawahara K, Nishiyama K, Seki N, Nakagawa M. Functional role of LASP1 in cell viability and its regulation by microRNAs in bladder cancer. Urol Oncol. 2010; [Epub ahead of print] PMID: 20843712.

73. Yoshino H, Enokida H, Chiyomaru T, Tatarano S, Hidaka
H, Yamasaki T, Gotannda T, Tachiwada T, Nohata N, Yamane T, Seki N, Nakagawa M. Tumor suppressive microRNA-1 mediated novel apoptosis pathways through direct inhibition of splicing factor arginine/serine-rich 9 (SRSF9/SRp30c) in bladder cancer. Biochem Biophys Res Commun. 2012; 417: 588-93.

74. Nohata N, Hanazawa T, Kikkawa N, Mutallip M, Fujimura L, Yoshino H, Kawakami K, Chiyomaru T, Enokida H, Nakagawa M, Okamoto Y, Seki N. Caveolin-1 mediates tumor cell migration and invasion and its regulation by miR-133a in head and neck squamous cell carcinoma. Int $\mathrm{J}$ Oncol. 2011; 38: 209-17.

75. Chiyomaru T, Enokida H, Tatarano S, Kawahara K, Uchida Y, Nishiyama K, Fujimura L, Kikkawa N, Seki N, Nakagawa M. miR-145 and miR-133a function as tumour suppressors and directly regulate FSCN1 expression in bladder cancer. Br J Cancer. 2010; 102: 883-91.

76. Mutallip M, Nohata N, Hanazawa T, Kikkawa N, Horiguchi S, Fujimura L, Kawakami K, Chiyomaru T, Enokida H, Nakagawa M, Okamoto Y, Seki N. Glutathione S-transferase P1 (GSTP1) suppresses cell apoptosis and its regulation by miR-133alpha in head and neck squamous cell carcinoma (HNSCC). Int J Mol Med. 2011; 27: 345-52.

77. Uchida Y, Chiyomaru T, Enokida H, Kawakami K, Tatarano S, Kawahara K, Nishiyama K, Seki N, Nakagawa M. MiR-133a induces apoptosis through direct regulation of GSTP1 in bladder cancer cell lines. Urol Oncol. 2011; [Epub ahead of print] PMID: 21396852.

78. Wong TS, Liu XB, Wong BY, Ng RW, Yuen AP, Wei WI. Mature miR-184 as Potential Oncogenic microRNA of Squamous Cell Carcinoma of Tongue. Clin Cancer Res. 2008; 14: 2588-92.

79. Crawford M, Batte K, Yu L, Wu X, Nuovo GJ, Marsh CB, Otterson GA, Nana-Sinkam SP. MicroRNA 133B targets pro-survival molecules MCL-1 and BCL2L2 in lung cancer. Biochem Biophys Res Commun. 2009; 388: 483-9.

80. Song G, Zhang Y, Wang L. MicroRNA-206 targets notch3, activates apoptosis, and inhibits tumor cell migration and focus formation. J Biol Chem. 2009; 284: 31921-7.

81. Carmona-Saez P, Chagoyen M, Tirado F, Carazo JM, Pascual-Montano A. GENECODIS: a web-based tool for finding significant concurrent annotations in gene lists. Genome Biol. 2007; 8: R3.

82. Nogales-Cadenas R, Carmona-Saez P, Vazquez M, Vicente C, Yang X, Tirado F, Carazo JM, Pascual-Montano A. GeneCodis: interpreting gene lists through enrichment analysis and integration of diverse biological information. Nucleic Acids Res. 2009; 37: W317-22.

83. Childs G, Fazzari M, Kung G, Kawachi N, BrandweinGensler M, McLemore M, Chen Q, Burk RD, Smith RV, Prystowsky MB, Belbin TJ, Schlecht NF. Lowlevel expression of microRNAs let-7d and miR-205 are prognostic markers of head and neck squamous cell carcinoma. Am J Pathol. 2009; 174: 736-45. 
84. Kikkawa N, Hanazawa T, Fujimura L, Nohata N, Suzuki H, Chazono H, Sakurai D, Horiguchi S, Okamoto Y, Seki N. miR-489 is a tumour-suppressive miRNA target PTPN11 in hypopharyngeal squamous cell carcinoma (HSCC). Br J Cancer. 2010; 103: 877-84.

85. Wu WY, Xue XY, Chen ZJ, Han SL, Huang YP, Zhang LF, Zhu GB, Shen X. Potentially predictive microRNAs of gastric cancer with metastasis to lymph node. World $\mathrm{J}$ Gastroenterol. 2011; 17: 3645-51.

86. Szafranska AE, Davison TS, John J, Cannon T, Sipos B, Maghnouj A, Labourier E, Hahn SA. MicroRNA expression alterations are linked to tumorigenesis and non-neoplastic processes in pancreatic ductal adenocarcinoma. Oncogene. 2007; 26: 4442-52.

87. Song T, Xia W, Shao N, Zhang X, Wang C, Wu Y, Dong J, Cai W, Li H. Differential miRNA expression profiles in bladder urothelial carcinomas. Asian Pac J Cancer Prev. 2010; 11: 905-11.

88. Ambs S, Prueitt RL, Yi M, Hudson RS, Howe TM, Petrocca F, Wallace TA, Liu CG, Volinia S, Calin GA, Yfantis HG, Stephens RM, Croce CM. Genomic profiling of microRNA and messenger RNA reveals deregulated microRNA expression in prostate cancer. Cancer Res. 2008; 68: 616270.

89. Sarver AL, French AJ, Borralho PM, Thayanithy V, Oberg AL, Silverstein KA, Morlan BW, Riska SM, Boardman LA, Cunningham JM, Subramanian S, Wang L, Smyrk TC, Rodrigues CM, Thibodeau SN, Steer CJ. Human colon cancer profiles show differential microRNA expression depending on mismatch repair status and are characteristic of undifferentiated proliferative states. BMC Cancer. 2009; 9: 401.

90. Ma Y, Zhang P, Yang J, Liu Z, Yang Z, Qin H. Candidate microRNA biomarkers in human colorectal cancer: Systematic review profiling studies and experimental validation. Int J Cancer. 2011; [Epub ahead of print] PMID: 21671476

91. Bandres E, Cubedo E, Agirre X, Malumbres R, Zarate R, Ramirez N, Abajo A, Navarro A, Moreno I, Monzo M, Garcia-Foncillas J. Identification by Real-time PCR of 13 mature microRNAs differentially expressed in colorectal cancer and non-tumoral tissues. Mol Cancer. 2006; 5: 29.

92. Zuker M. Mfold web server for nucleic acid folding and hybridization prediction. Nucleic Acids Res. 2003; 31: 3406-15.

93. Kanehisa M, Goto S, Sato Y, Furumichi M, Tanabe M. KEGG for integration and interpretation of large-scale molecular data sets. Nucleic Acids Res. 2012; 40: D109-14. 